Journal of Contemporary Educational Research

Review Article

\title{
Research on the path of Improving College Counselors' professional ability under the background of innovation and entrepreneurship
}

Peiwei Zhang

Guizhou Education University, Guiyang 550018, Guizhou Province, China

Funding: Guizhou Province College Teaching Content and Curriculum System Reform Project "Research on

'Two-way Construction' System of Innovative Entrepreneurship Education and Ideological and Political Education in Colleges and Universities-Taking Guizhou Education University as an Example" (2019088); Guizhou Provincial Department of Education Humanities and Social Sciences Research Project "Research on the path of college counselors' professional ability under the background of innovation and entrepreneurship-taking Guizhou Education University as an example" (2019fdy031).

\begin{abstract}
Innovation is the first driving force leading economic and social development, and innovation and entrepreneurship education is an important engine for promoting national economic growth. At present, our country is at the critical node of comprehensively deepening reform, decisively building a moderately prosperous society in an all-round way, and realizing the two centenary goals, and we must firmly grasp the initiative in economic development. College students have always been a barometer of the development of the times, and how innovative and entrepreneurial college students is related to the future and destiny of the country's economic development. The key to the cultivation of college students' innovative and entrepreneurial ability lies in education, and the key to the effect of education lies in teachers. As an important component and supplement to the faculty of colleges and universities, counselors play a key role in the growth of college students. It can be said that the professional ability construction of college counselors is very important to the cultivation of innovative and entrepreneurial talents and cannot be replaced. From the perspective of innovation and entrepreneurship education, this article discusses the development status of domestic and foreign college counselors' professional ability construction, discusses the problems and causes of college counselors' professional ability construction, and proposes a path to optimize the professional ability construction of counselors.
\end{abstract}

Keywords : Innovation and entrepreneurship; Counselor; Professional ability; Path

Publication date: August, 2020

Publication online: 31 August, 2020

*Corresponding author: Peiwei Zhang, zapeyn@163. com

The 19th National Congress of the Communist Party of China pointed out that innovation is the first driving force for development, and encouraging entrepreneurship to drive employment is the strategic support for building a modern economic system. At present, our country is at the critical node of comprehensively deepening reform, decisively building a moderately prosperous society in an all-round way, and realizing the two centenary goals, and we must firmly grasp the initiative in economic development. College students are the main force in the development of the motherland in the future. Their ability to innovate and entrepreneurship is related to the country's economic development and its future and destiny. As an important component and supplement to the faculty of colleges and universities, counselors play a key role in the growth of college students. In other words, the professional ability construction of college counselors is very important to the cultivation of innovative and entrepreneurial talents and cannot be replaced. Carry 
out the fundamental task of fostering virtue through education, cultivate socialist qualified builders and reliable successors with comprehensive development of morality, intelligence, physical education, art and labor, and cultivate students' innovative spirit, entrepreneurial practice ability and a good sense of social responsibility. This is the new era bestowed on college counselors Historical mission. Strengthening the professional ability construction of college counselors under the background of innovation and entrepreneurship is a key measure to keep in mind the mission of fostering virtue through education, not forget the original intention of education to serve the country, fully implement the party's educational policy, and cultivate innovative and entrepreneurial talents.

\section{The Status Quo and the Development of Counselors' Professional Ability under the Background of Innovation and Entrepreneurship Education}

\subsection{The professional ability development of college counselors in some developed countries in the background of innovation and entrepreneurship}

In 1998, UNESCO first proposed the concept of entrepreneurship education in the report on higher education in the new century. Since then, innovation and entrepreneurship education has sprung up like mushrooms ${ }^{[1]}$. The continuous development of innovation and entrepreneurship has put forward higher requirements for the vocational ablity of innovation and entrepreneurship education teachers. Although some colleges in developed countries do not set up "counselor" positions, they have similar positions, such as "student affairs consultant" and "student affairs instructor". Consultants and instructors generally have professional knowledge related to innovation and entrepreneurship education, and can provide college students with relevant guidance on innovation and entrepreneurship. Innovation and entrepreneurship education first emerged in the United States. After decades of development, the United States has achieved a series of research results in college students' innovation and entrepreneurship education ${ }^{[2]}$. The United Kingdom promotes the professional competence of innovation and entrepreneurship teachers by designing related specific plans, and has issued a series of policies to train more innovation and entrepreneurship faculty. The German government clearly relies on higher education to cultivate entrepreneurs, which requires more and better quality teachers worked on innovation and entrepreneurship education. Japanese scholars suggested that by providing more resources to strengthen the professional abilities of student affairs workers, innovation and entrepreneurship education can be further developed ${ }^{[3]}$. Through analysis of education in some developed countries, it can be seen that a considerable number of countries have begun to focus on improving their professional abilities, and pay more attention to the student affairs consultants who are responsible for answering problems of start-up in colleges. At the same time, the governments of these countries also provide a lot of resources to strengthen the professional capabilities of student affairs workers.

\subsection{The status quo and the development of counselors' professional ability under the background of Chinese innovation and entrepreneurship education}

After decades of development, China has achieved positive results in the construction of college counselors' professional ability and leapfrog development in related theoretical research and practical exploration. but they also face many problems. For example, counselors are in lack of personal innovation awareness and ability, which seriously restricts the cultivation of innovative talents. As an educator who has direct contact with students, counselors should always provide all kinds of consultation and counseling to college students on the path to entrepreneurship. However, "Innovation and Entrepreneurship" is a complex system, involving professional knowledge in education, management, psychology, economics, law and other related industries, and requires counselors to have wide range of knowledge and abilities. The thresholds of various industry are inconsistent, especially in some high-tech development industries, even the insiders may have difficulties in guiding people, let alone the college counselors with different subjects backgrounds. On the one hand, due to the lack of systematic training, counselors are often in the situation of "spirit is willing but flesh is weak" when carring out the innovation and entrepreneurship education. On the other hand, most of the counselors have no experience in start-up, and many of them entried colleges as counselors as soon as they graduated. They don't know much about the current status of the industry and the entire entrepreneurial environment. The guidance for students can often only be "on paper." and is lacking in professionalism. At the same time, college students' innovation and entrepreneurship are not all smooth sailing. Relevant survey data show that in recent years, the probability 
of successful entrepreneurship among Chinese college students is less than $2 \%$, which shows that it is not easy for college students to succeed in entrepreneurship. It is not as simple as imagined. Passion and dreams alone are not enough. Dreams and feelings are not enough. Therefore, conducting correct psychological counseling to college students who are interested in entrepreneurship is particularly important. However, many counselors are short of psychological knowledge and unable to accurately grasp the psychological dynamics of students, and naturally unable to meet their specific psychological demands timely.

\section{Causes of Counselors' Professional Ability Development under the Background of Innovation and Entrepreneurship}

\subsection{College counselors lack the innovation and innovative thinking}

At present, the main job responsibility of college counselors in our country is to do a good job in ideological and political education of college students. At the same time, counselors need to spend more energy on dealing with the daily work of college students, such as the construction of study style and class, psychological crisis intervention, scholarship evaluation, career planning and employment guidance, etc. This makes college counselors busy with all kinds of transactional tasks, no time for systematic theoretical study and practical research, and no time to study the connotation of innovation and entrepreneurship. The administrative way of working is contrary to innovative thinking, which affects the establishment of the counselors' innovative consciousness and thinking.

\subsection{College counselors lack professional knowledge and ability to carry out college students' innovation and entrepreneurship education}

Innovation and entrepreneurship education is a systematic project that requires counselors to have related theoretical knowledge, practical experience, and comprehensive qualities. Due to the different academic backgrounds and knowledge experience of counselors, most counselors have not received professional and systematic learning of innovation and entrepreneurship knowledge, nor do they have practical experience in innovation and entrepreneurship education. They are well-meaning but ineffectual instructors when educating college students in innovation and entrepreneurship. They lack the knowledge and ability of innovation and entrepreneurship education, which cannot meet the requirements of college students for the instructor of innovation and entrepreneurship education.

\subsection{College counselors are in short of effective ways to carry out college students' innovation and entrepreneurship education}

At present, colleges have set up related courses such as the Career Planning and Employment Guidance, the Innovation and Entrepreneurship courses, etc. But counselors are entangled in complicated student affairs, so that they are shot of time in devoting themselves to teaching and scientific research activities, are difficult to form own knowledge system. As a result, there are little transformation of scientific research achievements, which has also become one of the reasons for restricting the development of innovative and entrepreneurial capabilities of counselors.

\section{The Way to Improve the Professional Ability of Counselors under the Background of Innovation and Entrepreneurship Education}

\subsection{Highlight the importance of college counselors in innovation and entrepreneurship education}

Socialism with Chinese characteristics has entered a new era. Higher education should focus on cultivating socialist builders and successors with all-round moral, intellectual, physical and aesthetic grounding, in addition to a hard-working spirit, as well as cultivating college students' sense of social responsibility, innovative spirit, and entrepreneurial ability. Counselors, an important part of the college teachers, are entrusted of the historical missions of improving the innovation and entrepreneurship quality of college students by the times. Under the current national call for innovation and mass entrepreneurship, the establishment of a professional, professional and expert instructor team is the key to promoting the innovation and entrepreneurship of college students. In the new era, facing new situations and new requirements, college counselors must fully understand the key role of high-quality innovative and entrepreneurial talents in national economic construction, take the initiative to assume the mission of fostering talents, and actively act as counselors in the cultivation of innovative and entrepreneurial talents. It is an important role in China, mastering the knowledge and ability of scientifically leading college students to innovate and start businesses.

\subsection{Stimulate the endogenous motivation of}




\section{counselors' innovation and entrepreneurship education}

A good ecological environment in college is a prerequisite for stimulating the vitality and endogenous motivation of the counselor's innovation and entrepreneurship education. Adding some innovation and entrepreneurship competitions to the counselors' year-end assement and professional titles evaluation, such as the China International College Students' "Internet Plus" Innovation and Entrepreneurship Competition, the Innovation Creativity Entrepreneurship, and etc. Strengthening the financial supports and rewards, which can stimulate the endogenous motivation of counselors. To Create a strong and positive atmosphere for innovation and entrepreneurship, colleges can actively promote the theme of innovation and entrepreneurship education through school newspapers, community publications, Weibo, Wechat public accounts, TikToks account, radio stations and other medias, establishing a model culture, and positively promote counselors who have outstanding performance in innovation and entrepreneurship education. Counselors receive nourishment and motivation in a good atmosphere of innovation and entrepreneurship.

\subsection{Improve the innovation and entrepreneurial ability improvement mechanism of college counselors}

The Party(the Communist Party of China)and the League(the Communist Youth League of China) organizations in universities should play the important role of organizational security, and build complete the mechanism of the counselors' ability in the innovation and entrepreneurship from the top-level design, arrangements, supervision and evaluation in macro-level. In the admission mechanism of counselors, the innovation consciousness, entrepreneurial ability, and innovation and entrepreneurial experience of counselors are included in the key inspection scope, and talents with certain innovation and entrepreneurship capabilities are targeted to enrich the college counselor team. In the annual continuing study for college teachers, we pay more attention to the training of counselors' innovation and entrepreneurship ability. Colleges should guarantee the sufficient time for the training classes and improve the course structure, and allocate corresponding teachers to provide a strong faculty for the counselors' innovation and entrepreneurship ability. Provide a platform for counselors to improve their innovation and entrepreneurship capabilities, encourage counselors to guide college students to take part in the "Innovation Creativity and Entrepreneurship" contest, "Youth Red Dream Building Journey" activities, college students' scientific research projects, etc., and provide them with adequate funding guarantees and a good environment. Outstanding instructors will improve their innovation and entrepreneurship capabilities through various forms such as overseas study visits and advanced education.

\section{References}

[1] Agnes M. Watanabe-Muraoka. The national system of university counselling in Japan[J]. International Journal for the Advancement of Counselling, 2014(1).

[2] Lothar RM. Patterns of student counselling in five continents: Summary, comparison and outlook[J]. International Journal for the Advancement of Counselling, 2012(1).

[3] Tat-wing L, Oi-ling S, Paul ES. Faculty Stressors, Job Satisfaction, and Psychological Distress Among University Teachers in Hong Kong: The Role of Locus of Control[J]. International Journal of Stress Management, 2012(2). 